\title{
Professional Development of Early Childhood and Language Education Teachers for Sustainable Development.
}

\author{
Christy Omotuyole ${ }^{1}$ Afoma R. Okudo ${ }^{2}$ \\ Department of Arts and Social Sciences Education Faculty of Education, University of Lagos, Nigeria
}

\begin{abstract}
The man who uses yesterday's formula in today's world will not be in business tomorrow. This statement buttresses the fact that we live in a rapid changing world such that whatever knowledge and skills teachers acquired in their pre-service training becomes stale very fast as new challenges and realities emerge in the socio-economic and political environment. In this respect, professional development serves to bridge the gap between the present and the future. This paper sets out to examine teachers' accessibility to professional development as a tool for sustainable development. Descriptive survey design was used and questionnaire was the instrument used for the collection of data. One hundred and fifty teachers were randomly selected from the urban and rural areas of Lagos State, Nigeria. Three teachers were randomly selected from the early childhood classrooms which are as well Nigerian language classrooms of both the urban and rural centres. The population of the study comprises all the Early Childhood Education teachers who are as well Nigerian language teachers. The sample of the study consists of 150 teachers of mixed sex drawn from both public and private schools of the urban and rural schools of the six educational districts in the state. Two research questions were drawn and descriptive statistics was used to analyse the data. The study found that for most teachers, training end as soon as they graduate. No opportunities exist for updating and enhancement of their knowledge and skills in order to ultimately improve on their classroom practice. Findings also revealed that government-sponsored in-service training workshops and seminars for pre-primary school teachers are very few and irregularly organized.
\end{abstract}

Key words: Teacher professional development, teacher competence, sustainable development, employability.

\section{Introduction}

Teaching is the process by which a teacher guides the learners in the acquisition of knowledge, skills and attitudes with the intention of developing cognitive, psychomotor, affective and aesthetic goals in the students. It is essentially a system of interactions involving the teacher, the learner and the learning materials, thus, forming a triangular interaction.

During the early years of teaching, anybody at all could be called upon to teach. In fact, many of the teachers were practicing one form of trading or the other and the early teacher training colleges hoped to build a profession out of their practice. With the coming of the British into Nigeria, they established the typical missionary schools. The schools had curriculum and programmes that were hardly relevant to the needs of the society. The schools taught values that were alien to the societies they were located therein. The products were educated for no task in particular but to serve the missionaries and colonial masters of that time.

\section{Historical Development of Teachers in Nigeria: Pre and Post -Colonial Era}

Teaching was in two folds. First, as an apprentice teacher and then on the job training. The prospective teachers were required to serve first as auxiliary teachers under close supervision of the European masters and pastors before going into training.

Early teacher training colleges were established but could not produce "teachers" but individuals with basic learning components of teaching most of which are bible studies and basic subjects like English and Arithmetic. First teacher training was aimed at becoming pupils' teachers and catechists/evangelists. Under this arrangement, the syllabus consisted of the New Testament, preaching and theology, hygiene, geography, history, English, carpentry and masonry. This apprenticeship kind of training emphasized on the job training under the watchful eye of the master, teacher or pastor.

Later, student teachers were drawn from elementary VI, after serving as auxiliary teachers for two years; they were qualified after training as pupils' teachers. The teachers then had to teach at the end of all training programmes for some time before moving forward in their studies. Teachers who are sponsored to higher education have to serve their sponsors for few years before they can be free.

With the approach of independence, (1950 - I 960s), the Nigerian citizens had the desire for good health programmes, expansion of transportation, communication and agriculture according to Asiedu \& Kroft (1985). These created possibilities for change and the provision of educational facilities alone has the answers to these demands. Teacher training institutions were therefore established in different parts of the country. These 
Colleges went on to produce teachers at the Grade three, and later Grade two levels. At the end of each training period, teachers had to work for their sponsors for a minimum of two years before they can go back for further education or be free to leave. Before the teachers could go on to the next class, he must have received three good annual reports to his credit. This is a more stringent measure for the teachers, but they endured and went on.

With demands for schooling, school expansion was inevitable. Existing schools were expanded and governments establishing new ones. This means more teachers would be required, and therefore needs to be employed. In 1976, when the Universal Primary Education (UPE) Scheme was launched, to satisfy the yearnings of Nigerians for more educational provisions especially for children, UPE teacher training schools were established. These schools trained prospective teachers for nine months to two years, thus the influx of everybody into teaching. From a specialized profession, teaching became the dumping ground for all, especially those that were not qualified for other jobs or further education. This is the situation till date.

In Fafunwa's words (1991), suddenly practically, all cooks, stewards, and baby nurses disappeared from the various households in Nigeria and enrolled for teacher training. The UPE is one of the periods in the history of teaching when it was purely polluted and even filled up by people who should never be teachers in the first place. But the number of these kinds of teachers swells the number of teachers up to date.

\section{Concept of Teacher Education and Teacher Professional Development}

Teacher education refers to the policies and procedures designed to equip prospective teachers with the knowledge, attitudes, behaviours and skills they require to perform their tasks effectively in the classroom, school and wider community.

Although ideally it should be conceived of, and organised as, a seamless continuum, teacher education is often divided into these stages:

- initial teacher training / education (a pre-service course before entering the classroom as a fully responsible teacher);

- induction (the process of providing training and support during the first few years of teaching or the first year in a particular school);

- teacher development or continuing professional development (CPD) (an in-service process for practicing teachers).

Teacher professional development refers to skills and knowledge attained for both personal development and career development. This encompasses all types of facilitated learning opportunities ranging from college degrees to formal course work, conferences and informal learning opportunities situated in practice. Teacher professional development as defined by Bartram and Walton (2002) is the constant and ongoing re-energizing of a teacher's technique whilst the teacher is actually on the job. Its real purpose is to provide continuing refreshment and critique of what is and what should be happening in the classroom. In the same vein, Olujide (2004) defines it as a life-long form of education for the improvement of the teacher and the educational system. According to Mohammed (2006), teachers' professional development has two main phases: initial preparation and continuing professional development. Continuing professional development, according to him,may be regarded as all forms of in -service', 'continuing education', 'on-the-job-training', 'workshops', 'post-qualification courses' etc; whether formal or informal, structured or unstructured, teacher-initiated or system-initiated, accredited or not.

Indeed Samplelesson (2009) echoes that as global business competition shifts from efficiency to innovation and from enlargement of scale to creation of values, management needs to be oriented towards the strategic use of human resources. Teacher education must therefore be directed towards creating values for the society and for teachers themselves. In addition, the dire need for professional development of teachers was heightened in the words of John Maxwell (2003) when he asserts that the man who uses yesterday's formula in today's world will not be in business tomorrow. This statement buttresses the fact that we live in a rapidly changing world such that whatever knowledge and skills teachers acquired in their pre-service training becomes stale very fast as new challenges and realities emerge in the socio-economic and political environments.

Jegede (as cited in Olojede 2009) states that opportunities for continuing professional development must be created to re-skill the potential teacher, re-motivate the interested teacher, retrain the dedicated teacher and the practicing teachers. Lawal and Adeosun (2007) supported that it is non-debatable that high quality of professional development is an essential component of any effective educational programme.

The ultimate purpose of professional development therefore is to promote effective teaching that results in learning gains for all students. Summing it up, Okebukola (2009) states that a nation cannot hope for a top quality education system as long as her schools are manned by second-rate teachers, since the quality of teachers is largely dependent on the quality of training they received before entering the profession (pre-service) and while they are on the job (in-service).

The success of any educational enterprise is therefore believed to hinge on the quality of teaching that goes on in 
the classrooms. Storey (2006) emphasised this importance when he stated that competencies are essential for the well-being of teachers; as those teachers who are less competent will be less satisfied with their jobs, less efficient and with lower well-being; this will definitely impact the teaching process with its outcomes in pupils. Teachers who have specific preparation, knowledge and skills in early childhood and language education are more likely to engage in warm, positive interactions with children, offer richer language experiences and create more high-quality learning environments.

Sustainable development as described by Kundan in (Ugoh, 2008) is a construct, which envision development as meeting the need of the present generation without compromising the needs of the future generation. It implies that while professional development of teachers meets the need of the present it does not compromise the ability of the future generations to meet own needs. Nevertheless, this ability to meet the needs is determined by human capital (through education, technology advance) and through physical capital (machine, tool etc). Kundan argues that continued sustainable development is only possible or assured when it is agreed and indeed concrete steps are taken to raise the level of literacy and numeracy in any society. Educational institutions- their programmes and teachers development are therefore, the tools with which to achieve development and its sustainability. In fact, Holmes group (as cited by Passos 2009) indicated that excellent curricular, materials, infrastructure will not improve the quality of education but good result can be achieved with quality teaching for the entire school curriculum is filtered through the heart and minds of classroom teacher, making the quality of learning dependent on the quality of teachers. Professional development of teachers therefore as a veritable tool for sustainable development is the development of teachers to meet present need without compromising the needs of the future generation.

The importance of teachers' competence cannot be overemphasised as Okebukola (2009) buttresses this point that no nation can hope for a top quality education system as long as her schools are manned by second-rate teachers. More so, since the quality of teachers is largely dependent on the quality of training they received before entering the profession (pre-service) and while they are on the job (in-service).

\section{Approaches to Teachers' Professional Development}

Various approaches to teachers' professional development are described below as ways to address diverse teachers' needs, skills and knowledge.

1. Face to Face Institutional Model: In this model, the training institution offers in-service training programme on its premises using direct face-to-face training approach. The merit of this approach is that there is a direct and sustained interaction between participants and resource persons. The limitation of this approach is that it cannot be used when the institution wants to train a very large number of participants within a short time.

2. Cascade Model: In this model, the number of persons to be trained is very large and training design is built on two or three tier systems. In the first level the key resource persons are given training. They train resource persons who in turn train teachers. The advantage of this model is that a large number of teachers can be trained within a short duration of time.

3. Peer Observation: Peer observation is based on the three-phase model of Planning, Observation Feedback known as clinical supervision (Cogan, 1973). Pairs of teachers, who have been trained to do so, visit each other's classes and provide each other with insights and advice on their teaching. Teachers themselves decide on the focus for observation and the observation instrument, and reflect on the results of the observation based on their development needs.

4. Study Groups: Study groups involve teachers in reviewing professional literature or analyzing samples of students' work. Groups structure their interactions around scripts or agendas called protocols (Birchak, Connor, Crawford, Kahn, Kayer, Turner \& Short, 1998) and use lesson plans or samples of students' work as input for discussion.

5. Dialogue Journal: According to Peyton (1993), dialogue journals are conversations in writing. Although they have been widely used in language and literacy classrooms since their first documented use (Staton, Shuy, Peyton, \& Reed, 1998), they have only recently found its place in the professional development field. 


\section{Statement of the problem}

There is no gainsaying that those who are involved in Early Childhood and Nigerian language education should possess the relevant skills and knowledge that properly shape children. At least, two decades of research confirm that teacher qualifications and skills significantly affect the quality of care and education provided for young children. However, Coffman and Lopez (2009) assert that despite researches linking teacher education and child outcomes, most preschool teachers lack the qualifications, clinical skills and professional competence needed to provide high quality learning experiences for young children. This is demonstrated in the rigorous academic exercises and teachers' instructions that focus only on isolated skills development which are common practices in most of our early childhood classrooms. Hence, this dismal state spells doom for educational development in Nigeria if this shoddy performance continues unabated

There is therefore, the need to assess the effects of professional development of teachers as a tool for sustainable development among Early Childhood and Nigerian language teachers in Lagos State,Nigeria.

\section{Purpose of study}

The main purpose of this study is to assess the impacts of professional development of teachers as a tool for sustainable development among Early Childhood and Nigerian language teachers in Lagos State. The specific objectives of this study are to:

1 Find out the extent to which ECE teachers are professionally trained for sustainable development;

2. examine the impact of ECE and Nigerian language teachers' professional development as a tool for sustainable development.

\section{Research Questions}

1. To what extent are the ECE and Nigerian language teachers professionally trained for sustainable development?

2. What impacts does the teachers' professional development have for sustainable development?

\section{Methodology}

\section{Research design}

This study adopted the descriptive survey designs. The design is appropriate for this study as it enabled the researcher to describe the sampled teachers accurately.

\section{Population and Sample}

The population comprised all nursery school teachers in Lagos States of Nigeria.The sample for the study comprised 150 teachers randomly selected from public and private early childhood schools of the six educational districts of Lagos State. Lagos Educational Area is divided into six education districts and the districts are further divided into twenty (20) Local Government Education Authorities (LGEAS). Using the stage stratified sampling technique; the researchers divided the twenty Local Government Education Authorities into two categories: urban and rural areas.Random sampling technique was then employed to select ten Local Government Education Areas based on rural and urban classifications. One hundred and fifty teachers were randomly selected from 50 approved schools and those fifty are from 10Local Governmentsof which 25 are public and 25 are private schools respectively. Using simple random sampling technique, 4 teachers were selected from the public ECE classroomsand 3 teachers from private ECE classroom.

\section{Instrumentation}

A Questionnaire titled Professional Development of Early Childhood and Nigerian languages Teachers for Sustainable development constructed by the researchers was the major instrument for data collection. The questionnaire was divided into two sections: A and B. Section A contains the demographic information of the respondents while section $\mathrm{B}$ is a close ended questions based on the Likert's 4 point scale measurement (Agreed, Strongly Agreed, Disagreed and Strongly Disagreed) designed in line with the objectives of the study.

\section{Validation of Instruments}

The face validity of the instrument was carried out by experts/colleagues in the field of Early Childhood and Language Education; thereafter a pilot study was later conducted with 50 teachers from a different early childhood schools which were not part of the study group to revalidate the instrument. With respect to reliability of the instrument, cronbach alpha method was used and the reliability yielded a coefficient of 0.80 .

\section{Procedure for Data Collection}

With the help of trained research assistants, the researchers administered the instruments to the subjects in their various Early childhood Nursery schools. Out of the 175 copies of questionnaire, 150 were completely 
filled and retrieved from the respondents for analysis giving a 95\% return rate. The questionnaire administration lasted for 3 weeks

\section{Data Analysis \\ Table 1}

To determine the demographic profiles of Early childhood as well as Nigerian languages education teachers in the study, a cross tabulation was performed using teacher qualifications, areas of specialization, sex and years of working experience.

\begin{tabular}{|l|l|l|l|l|l|}
\hline Location & $\begin{array}{l}\text { WASC } \\
\text { Equivalent }\end{array}$ & N.C.E & B.Ed/B.A/B.SC & $\begin{array}{l}\text { M.Ed/M.A/M.SC or } \\
\text { Equivalet }\end{array}$ & TOTAL \\
\hline Urban & $6(7.90 \%)$ & $47(61.84 \%)$ & $18(23.68 \%)$ & $5(6.57 \%)$ & $76(100 \%)$ \\
\hline Rural & $15(20.27 \%)$ & $49(66.22 \%)$ & $7(9.46 \%)$ & $3(4.05 \%)$ & $74(100 \%)$ \\
\hline Total & $21(14 \%)$ & $96(64 \%)$ & $25(17.10 \%)$ & $8(5.33 \%)$ & $150(100 \%)$ \\
\hline & & & & & \\
\hline
\end{tabular}

The table above shows that $76 \mathrm{ECE}$ as well as Nigerian languages teachers in urban areas of Lagos, $61.84 \%$ of them had N.C.E, $23.68 \%$ of them were first degree holders while a negligible $6.57 \%$ and $7.90 \%$ had M.Ed and school certificates respectively.

In the rural areas, out of 74 ECE and Nigerian languages teachers, $66.22 \%$ of them had N.C.E, 9.46\% were first degree holders while only $4.05 \%$ had postgraduate qualifications and $20.27 \%$ were school certificate holders or its equivalent respectively. In summary, N.C.E holders constitute the largest percentage of teachers with $64 \%$ in both urban and rural areas. Teachers with B.Ed/B.A ranked second with $17.10 \%$ while WASC or its equivalent ranked third with $14 \%$ and Postgraduate degree holders ranked fourth with $5.33 \%$.

\begin{tabular}{|l|l|l|l|l|l|}
\hline S/N & \multicolumn{3}{|c|}{ Agree } & $\begin{array}{l}\text { Strongly } \\
\text { Disagree }\end{array}$ & Disagree \\
\hline Professional development programmes and in-service training of ECE teachers & $6(2.67 \%)$ & $41(28.10 \%)$ \\
\hline 1 & $\begin{array}{l}\text { My school provides in-service training for } \\
\text { teachers }\end{array}$ & $24(16.41 \%)$ & $10(6.67 \%)$ & $70(46.67 \%)$ \\
\hline 2 & $\begin{array}{l}\text { I enjoy financial support provided for staff } \\
\text { to attend course(s) }\end{array}$ & $10(6.67 \%)$ & $20(13.33 \%)$ & $64(42.67 \%)$ \\
\hline 3 & $\begin{array}{l}\text { I attend staff development programme for } \\
\text { sustainable development }\end{array}$ & $6(2.67 \%)$ & $60(40 \%)$ \\
\hline Impact of professional development as a tool for sustainable development & NIL & $82(54.67 \%)$ \\
\hline 4 & $\begin{array}{l}\text { I undertake self-improvement programme } \\
\text { for sustainable development }\end{array}$ & $8(5.33 \%)$ & $10(6.67 \%)$ & $90(60 \%)$ \\
\hline 5 & $\begin{array}{l}\text { Professional development of ECE teachers } \\
\text { is worthwhile }\end{array}$ & NIL & $40(26.67 \%)$ & $5(3.33 \%)$ \\
\hline 6 & $\begin{array}{l}\text { Benefits of professional development ends } \\
\text { with the teachers that are trained }\end{array}$ & $\begin{array}{l}100 \\
(66.67 \%)\end{array}$ & $40(26.67 \%)$ & $20(13.33 \%)$ \\
\hline 7 & $\begin{array}{l}\text { Benefits of professional development } \\
\text { enhances curriculum implementation }\end{array}$ & $90(60 \%)$ & NIL \\
\hline
\end{tabular}

From table 2, 24 teachers strongly agreed that their school provides in-service training for the teachers, 6 agreed, and 41 disagreed while 79 teachers disagreed with the statement. Also, 10 respondents strongly agreed that they enjoyed financial support provided by their school, 10 respondents agreed, 70 strongly disagreed while the remaining 60 disagreed with the statement.

On the issue of impact of professional development as a tool for sustainable development, 8 respondents strongly agreed that they undertake self- improvement programme for sustainable development, none of them agreed, 82 strongly disagreed while 70 ECE teachers who are also Nigerian language teachers disagreed with the statement. Again, 90 teachers strongly disagreed that professional development of ECE teachers is worthwhile, 50 disagreed, 10 agreed while none strongly agreed with the statement. Ninety respondents strongly agreed that professional development of ECE teachers will enhance their curriculum implementation, 40 agreed, 20 strongly disagreed, while none disagreed with the statement. One hundred respondents strongly agreed that benefits of professional development end with the trained ECE teachers who are as well Nigerian language teachers, 40 agreed,5 strongly disagreed while 5 also disagreed with the statement.

\section{Discussion of Findings}

The study found out those ECE teachers who are also Nigerian language teachers do not attend in service training as was expected of them for their professional development and sustainable development and curriculum implementation. This disagrees with Mohammed (2006), who maintains that teachers' professional development should be on-going and be supported by the school. According to him, it should be encouraged among teachers because teachers face high expectations, new roles and demands. They therefore need new 
skills, knowledge and new roles which they can get through continuous professional development. The findings also disagreed with Samplelessson(2009) who echoes that as global business competition shifts from efficiency to innovation and enlargement of scale to creation of values, management needs to be oriented towards the strategic use of human resources. Based on that teacher's education especially ECE teachers should be directed creating values for the society and for themselves.

It was also found that most ECE as well as Nigerian languages teachers believed that professional development of ECE as well as Nigerian languages increases their chances of improves their pedagogic skills and this agreed with Ugoh(2008) who opined that sustainable development is a construct which envision development as meeting the need the present generation without comprising the need of the future generation

\section{Recommendations}

Specialized and focused in-service training is needed in Nigeria for Nursery school teachers to improve their performance. This is also a pointer to the fact that the general education that the teachers acquire in various colleges may not be adequate to keep them on the job because we live in a rapidly changing world such that whatever knowledge and skills teachers acquired in their pre-service training become stale very fast as new challenges and realities emerge in the socio-economic and political environments.

Public and private schools should make adequate budgetary allocation for professional development of the teachers and also encourage them to take advantage of all professional development opportunities.

Early Childhood Education as well as Nigerian languages programmes should be more focused at equipping teachers with best practices and the contents should be reviewed from time to time so as to keep them abreast of facts.

\section{References}

[1]. Bredekamp, S. \&Copple, C. (Eds.) (1997). Developmentally-appropriate practice in early childhood programs (Revised.ed.). Washington, DC: National Association forthe Education of Young Children.

[2]. Coffman, J. \& Lopez, M.E.,(2009). Raising Preschool Teacher Qualifications. Retrieved February 19,2009 from http://www.trust orearlyed.org.docs/NJabbottBrief.pdf

[3]. Dove, L.L. (2010). How professional development for teachers works. Retrieved September 29, 2010 from http://money .how stuff works.com/business/professional development/.

[4]. ERIC Digest (2002). Teacher competency.ERIC Digest 11. Retrieved from ERIC database http://ericae.net/edo/ed277685.htm

[5]. Fafunwa, A. B (1974).History of Education in Nigeria. London: George Allen \&Unwin Ltd.

[6]. Federal Republic of Nigeria. (revised 2004).National Policy on Education. Lagos: Federal Ministry of Information.

[7]. Fiene, R. (2002).13 Indicators of quality child care: Research update. National Resource Center for Health and Safety in Child Care: University of Colorado

[8]. Gestwicki, C. (2007). Developmentally appropriate practice: Curriculum and development. ( $3^{\text {rd }}$ ed.).Canada: Thomson Delmar Learning.

[9]. High/Scope Education Research Foundation (2010).Inservice teacher -training is the key to high quality early childhood programs. Retrieved september 29, 2010 from http://www.highscope.org/file.

[10]. Hohmann, M. \&Weikart, D.P (2002). (2nd Ed) Educating Young Children.High/Scope Press, United States of America.

[11]. Joki, R. A. (1982). Make teacher competency your policy. American school board journal 169. Retrieved July 13, 2009, from http://www.ericdigests.org/pre-922/teacher.htm.

[12]. Lawal, F. \&Adeosun, N. (2007). In-service training for primary school teachers: need, focus, problem and prospects inOlugasa, O(eds.) Literature and language: a drama of life-a festschrift in honour of Z.A. Adejumo. Lagos: Bprint.

[13]. Maduewesi, E. J. (1999). Early childhood: Theory and practice. Ibadan: Macmillan Nigeria publishers, Ltd.

[14]. Mason, J, (2003). Know your limits-then ignore them. Gainsville, Florida, USA: Bridge -Logos Publishers Inc.

[15]. Mohammed, A. M. (2006). Creating opportunities for continuing professional development of teachers: The National Teachers' Institute experience, A Lead Paper presented at the $1^{\text {st }}$ National Conference of the Faculty of Education, University of Abuja, 17 th-2 $1^{\text {st }}$, October

[16]. Mueller, D. P. (1997) The implementation of developmentally-appropriate practice in inner city primary - grade classrooms and its effects. Retrieved from the Eric database (ED 410- 324).

[17]. Nnabuo, P.O.M \&Asodike J.D ( 2013 ). Exploring education as a tool for sustainable development in Nigeria.European Scientific Journal. Vol8.No 10.

[18]. Ogunleye, A.O. (2000). An introduction to research methods in education and social sciences.Ilupeju - Lagos: Sunshine International Publications (Nig).Ltd.

[19]. Oke, C.O. (1990). A study of the effects of teacher mentoring programme on the teacher competence of beginning Secondary School Teachers.Unpublished Ph.d thesis, University of Lagos.

[20]. Olojede, K. (2009). Developing the grammatical competence of Lagos state public primary school teachers through school-based in-service training.Unpublished Ph.d thesis, University of Lagos.

[21]. Omotuyole, C.O. (2011). Effects of developmentally appropriate practice enhancement package on improving early childhood education teachers competence in Lagos and Ondo State, Nigeria.Unpublished Ph.D thesis, University of Lagos.

[22]. Osanyin, F. A, (2002).Early childhood education in Nigeria. Mushin - Lagos: Concept Publications Ltd.

[23]. Passos,AFJ.(2009). A comparative analysis of teacher competence and its effects in upper primary in Mosambique and other Sacmeq countries.Unpublished Ph.D thesis. University of Pretoria, Pretoria

[24]. Ugoh, S.C (2008). Oil politics and crisis of development in the Niger Delta: Journal of sustainable development.10, (2) 91-115

[25]. Umar, E.M. (2004). Professionalism in Teaching. Victoria Island, Lagos:National Open University of Nigeria.

[26]. United Nations Educatioal, Scientific and Cultural Organization. Education for Sustainable Development Retrieved May 12, 2013, from Unesco.org/images/0021/002162/216269e.pdf.

[27]. Shepard, L. \& Smith, M. (1988). Escalating academic demand in kindergarten: Some Nonsolutions.The Elementary School Journal,89(2),135-146.

[28]. Storey, A. (2006). Teacher competence as a basis for teacher education: Tuning teacher education curricula in five western Balkan countries. Retrieved September 12, 2009, from http://htk.hue.ee/tepe/wp-content/upload/spasovski. 